\title{
THE SOLIDARITY IN ADDRESSING TERMS OF RJ. PALACIO'S CHILDREN NOVEL 'WONDER': A SOCIOLINGUISTIC ANALYSIS
}

\author{
By : \\ Nur Jannah ${ }^{1}$, Dwijani Ratnadewi ${ }^{2}$ \\ TK Tunas Harapan Jaya, Surabaya ${ }^{1}$, Universitas Muhammadiyah Surabaya ${ }^{2}$ \\ paradise_azura@yahoo.com ${ }^{1}$, yani_rd@yahoo.com ${ }^{2}$
}

\begin{abstract}
Physical deficiencies sometimes cause bullying, but there are also many people who have sense of solidarity. "Wonder" (2012) by RJ. Palacio tells about a boy with this deficiency and this study was meant to analyze the addressing terms used among the characters illustrating solidarity. The aims of the research were to find kinds of solidarity addressing terms chosen by the characters; the reason and the kind of situation of using the addressing terms. The dialogues were framed and foregrounded to collect the data. Wardhaugh (2006) addressing terms and Lindenberg et. al. (2006) solidarity behaviour indicators were used as the main theories to analyze the data. The result revealed that there were four kinds of addressing terms found mentioning first name, kinship term, nickname, and endearment name used in various but mostly friendly, quarreling and serious situation.
\end{abstract}

Keywords: Addressing Terms; solidarity; solidarity behaviour.

People use many language varieties to communicate with others. Those varieties of language represent different functions or purposes. Sometimes people use the language to know each other character, show good manners, or to clarify their relationship. Holmes (2013:3) states that languages provide a variety of ways of saying the same thing - addressing and greeting others, describing things, paying compliments. Furthermore, she also mentions that language provides clues to social factors, such as the relationship between the people in the particular situation, and how the speaker feels about the person addressed. Addressing terms according to Yules (2010:273) are words or phrases for the person being talked or written to, similar to make a social connection by talking with people, so greeting and adding an addressing term reveals their social relationship. Meanwhile, forms of addressing based on Holmes' (2013:287) works derive from identity in the context, e.g. Your honor, Prime Minister." Addressing terms leads other interlocutors how to act around their community. By using the right addressing terms, a successful interaction may be gained; it saves face when people interact, and control how to speak. Addressing terms brings the speakers' belief of what the speaker wants other people think about him, what he thinks about the hearer, their relationship and what aims he has through his addressing terms (Parkinson in Azin and Afgari, 2015).

Conversations in novels can describe the language commonly used by the community, they can reflect the moral, cultural and social values of the community (Azin and Afgari, 2015). Addressing terms in novels are imitations of reality so that they can be added or subtracted according to the storyline, but they are still under the local social relationship principles frame. In social relations, addressing terms can be an indicator of the level of relationship between the two interlocutors but can also be used by interlocutors to treat interlocutors according to their wishes, just like a politeness strategy. In a novel that is obviously a man creation, the desire of the speaker is arranged by the author. 
Addressing terms used by characters in a novel may be carried out depicting solidarity, care, anger or any other feeling (Lindenberg, 2006). Solidarity was observed from a lesson the characters gave to be a true friend or being a friend who has special gift through their utterances. Beer and Koster (2009:15) mentions the word solidarity refers to the willingness to help others or to support the group one belongs to. The term solidarity is associated both with feelings and attitudes and with action. Lindenberg et al (2006:8) makes a framework which display how solidarity behavior forms. Certain environments such as schools, with teachers and school staff as models and also school rules can be used to create a sense of solidarity with students who have disadvantages. This environment of this novel supporteds other student to do good deed to the deformed face boy. Based on these reasons this research analyzed the kind of addressing terms that were used among the characters which convey solidarity, the way they were used and in what situation they were used.

\section{METHOD}

The data source of this study was children's novels entitled "Wonder" by Raquel Jaramillo Palacio which was published on February $14^{\text {th }} 2012$ and has been sold more than 5000 copies so far. It tells about friendship and solidarity among the characters. The data were obtained from the characters' utterances which have addressing terms in showing solidarity. The research used Paltridge's (2006) framing and foregrounding towards corresponding topics from the utterances in the novel to collect the data and found 11 dialogues from the novel to be analyzed. The indicators of addressing terms by Ronald Wardhaugh (2006) were used to select the data and the solidarity behaviour principles by Siegwart Lindenberg et.al. (2006) and Dell Hyme's context in Yules (2010) were applied used to analyze the data.

\section{FINDINGS AND DISCUSSION}

The research found that the characters of the novel used several kinds of addressing terms in showing their solidarity among them in different situation. August, the main character, found a different situation in his new school than he had previously worried. He got good new friends who even defended if other students insulted him, especially his face defect. He was almost certain before that he would not have a friend in his new school, but he found the opposite reality. The addressing terms those children and other characters chose to use in corresponding situation is elaborated as follows

\section{Mentioning First Name \\ Data 1}

(1) Suddenly someone was sitting down next to me. It was Jack Will. Jack.

(2) "What's up," he said, nodding at me.

(3) "Hey, Jack," I answered, waving my hand, which I immediately wished (4) I hadn't done because it felt kind of uncool.

It was in the classroom where Jack greeted August in the first day school and it created a friendly situation. Being a boy with facial deform, August came to his school unconfidently. To his surprise, his classmate greeted him, "What's up?". This slang which replaces "Hello" or "Hi" is usually said by teenagers to attract each other (Urbandictionary). Here, the slang used by 
Jack is not only used as attraction but also to show the willingness to start a conversation. It also functions as a greeting that can be proven by August's response, "Hey, Jack" (line 3). The interjection "Hey" used also functions as greeting (Thesaurus.com) and expresses pleasure to accept Jack's initiation. The greeting consists of the addressing terms of the first name 'Jack' which may also a sign of considerable intimacy (Wardhaugh, 2006:268). So, August uses "Hey" to answer Jack's greeting to show his pleasure by using the friend's first name 'Jack' to portray his happiness being greeted instead of his unconfident feeling before. This feeling is also confirmed by his gesture of waving hand.

Thus, the using of addressing terms with first name from August to Jack illustrates the willingness to cooperate shown from August utterance "Hey, Jack", of which behaviour contributes a common good situation in the conversation and it includes as cooperation of solidarity behaviour (Lindenberg et al, 2006:21).

\section{Data 2}

(1) "Geez, Julian, " said Jack. "Just shut up."

(2) "You shut up!" Julian yelled.

(3) "Come on, August," said Jack. "Let's just go to the library already."

(4) I walked toward Jack and followed him out of the auditorium.

(6) He held the double doors open for me, and as I passed by,

(7) he looked at me right in the face, kind of daring me to look back

(8) at him, which I did.

The situation shows how Jack quarreled with Julian about why he asked to August about his face deformed. In line 1, "Geez, Julian" that was stated by Jack illustrates that he protests to Julian to stop asking August about his face. It is supported by next utterance, 'Just shut up' which reveals Jack wants to Julian not to interfere August. In line 3, 'Come on, August' the phrase 'come on' has another meaning as "hurry up" (urbandictionary) which refers to August that the phrase is not only to show that Jack wanted August to follow him at that time but also to avoid a quarrel with Julian. The addressing terms of first name "August" which stated in line 3, may insist Jack's request to him directly and may reveal his care too (Holmes, 2013:4). It is strengthened by Jack's utterance 'Let's just go to the library already' which 'us' here may refer to Jack and August only whereas there is Julian with them. Jack's behaviour which is depicted by his utterances 'come on, August', 'Let's just go to the library already' and uses the first name 'August' reveals his help in times of need seem to show Jack's solidarity behaviour of altruism (Lindenberg, 2006:21). August, as occurs to a person who has deformity, certainly need to free himself from discussing that deformity, so Jack's request to follow him to the library really saves August from the uneasy situation.

\section{Using Kinship Term}

\section{Data 1}

(1) Mom came over, put her hands on my cheeks, and lifted my face to look

(2) at her. "I'm really, really sorry," she whispered. I could tell she was.

(3) "It's okay!" I said.

(4) "Via..."

(5) "Mom, it's fine." This time I meant it. She looked so genuinely sorry

(6) I just wanted to let her off the hook. 
In this data above, the conversation was between Olivia, August's sister, and her mother that took place in the kitchen. Via felt upset because her mother broke her promise to her. In this serious situation, her mother called her daughter's first name 'Via...' depicting that she worried about Via's feeling. It can be seen in line 2 which stated her mother's apology, the repeating word 'really' in the utterance 'I'm really, really sorry' may indicate that she admitted she was wrong and regretted for breaking a promise. Besides that, Via uses a kinship term 'Mom' which is usually used by older children and adolescents as honorific forms to their parents (Pongweni, 1983:13) as her response which may illustrate how Via tells and convinces her mother that she is okay. It can be enriched by adding 'It's fine' after using the kinship term to her mother to describe her condition. The kinship term 'Mom' may also function as a request from children to their parents, which in this case, to believe Via to refrain hurting other as a solidarity behaviour, trustworthiness (Lindenberg, 2006:22). Via, who is in adolescence period, wants her parents to trust her to solve her problem herself.

In brief, it can be inferred from the analysis above that Via uses a kinship term to show her attempt to convince her mother and to believe that she can make up her disappointment too.

\section{Data 2}

(1) "I have to invite everyone because I don't want anyone to get their

(2) feelings hurt if they find out other people are invited and they aren't, (3) okay?"

(4) "Okay," Mom agreed. "You even want to invite the 'what's the deal'

(5) kid?"

(6) "Yeah, you can invite Julian," I answered. "Geez, Mom, you should

(7) forget about that already."

(8) "I know, you're right.".

The dialogue above was in the kitchen where August and his mother were discussing about August's birthday party. In this friendly situation, he planned to invite all his friends. In line 6, August stated, "Geez, Mom, you should forget about that already", the phrase 'Geez, mom' said by August may mean an expletive to express surprise (Merriam-Webster) and also a form of August's protest to his mother. It can be seen from the previous utterance that August's mother stated, "You even want to invite the "what's the deal' kid?" (in line 4-6) which the phrase 'what's the deal' kid' is a nickname that August gave to Julian, his classmate (Palacio, 2012:28). August's mother statement here may illustrate her distrust of his son's decision. The addressing term of 'Mom' by August may also indicate that he wants a fair-share to his friends which also illustrate his fairness (Lindenberg et al, 2006:21). It can be enriched by August's previous statement, "I have to invite everyone because I don't want anyone to get their feelings hurt if they find out other people are invited and they aren't, okay?" (Line 1-3).

Thus, based on the analysis above what August stated and the using of the kinship term in the data is the use of solidarity behaviour of sharing situation.

\section{Calling Nickname}

\section{Data 1}

(1) "Dude, let him go inside so he can check it out," Jack Will told him,

(2) pushing past Julian and opening the door.

(3) "Go inside if you want," Julian said. It was the first time he looked at 
(4) me. I shrugged and walked over to the door. Julian moved out of the

(5) way quickly, like he was afraid I might accidentally touch him as I

(6) passed by him.

This conversation took place in the school lab of Breecher Prep school where Jack and Julian got a task from headmaster to introduce their school to the new student, August. In this friendly situation, Jack uses an addressing term 'Dude' refers to Julian that used mostly by young men to addressing other young men (Kiesling, 2004:282) which may index an affiliation and connection between them. This term may also illustrate to ameliorate the situation which can be shown by following utterance after 'Dude' in line 1. The utterance 'let him go inside so he can check it out' by Jack may indicate he wants Julian to fair share by showing the classroom to August. By using this term Jack hopes Julian would do his request. In line 3, Julian stated, "Go inside if you want" which may signal an agreement of Jack's opinion and also to show his fairness which in line with Lindenberg's idea (2006:21).

Thus, 'Dude' which is used by Jack in the data is one of addressing terms that indicate solidarity between friends. This is a fair share which shown to a new friend or even a stranger.

\section{Data 2 \\ (1) "Julian's a jerk," he whispered before Julian and Charlotte reached us. \\ (2) "But, dude, you're gonna have to talk." He said this seriously, like he \\ (3) was trying to help me. I nodded as Julian and Charlotte caught up to \\ (4) us. We were all quiet for a second, all of us just kind of nodding, \\ (5) looking at the floor. Then I looked up at Julian.}

This dialogue occurred at school where August would be going to and he was accompanied by Jack, Julian, and Charlotte to have a tour in that school. In the first meeting, obviously in August's condition which is not only as a newbie but also his deformity makes him not confident to talk. In line 1 shows the friendly situation which can be seen from the sentence 'Julian's a jerk' said by Jack, it may indicate his effort to have a talk with August. In line 2, Jack added 'But, dude, you're gonna have to talk' which the words 'dude' usually uses by a friend or acquaintance (McCrindle, 56) and shows solidarity. The phrase 'you're gonna have to talk' in that utterance may indicate Jack supports and requests August to talk with him or others. Jack's efforts in the dialogue above may depict a solidarity behaviour of Altruism (Lindenberg et al, 2006:21) that is reinforced by his utterances both in line 1 and 2 which illustrates Jack helps August in that situation.

From the analysis above, it can be proven that the addressing term 'dude' that Jack used to August shows solidarity even though they meet in the first time. It is also can be seen in the way Jack helps August by initiating to start the conversation.

\section{Data 3}

(1) "Thanks, Auggie," she giggled. "You know, that's what I like best about

(2) you. Ifeel like I can tell you anything."

(3) "Yeah?" I answered, nodding. I gave her a thumbs-up sign. "Cool

(4) beans."

This dialogue occurred between August and Summer, his school friend, that took place in the canteen. They were discussing about Halloween's costume which they would wear in the 
school. The utterance 'Thanks, Auggie' in such a friendly situation stated by Summer consists of an addressing term of nickname which is form from August's first name + letters 'ie' (line 1). This indicates that she is treating August as an intimate friend (Holmes, 2013:12). Nickname is also used to symbolize a friendship (Fasold, 1990:10) and includes positive nickname. It can be seen from the same line that stated 'You know, that's what I like best about you' which the phrase 'you know' here may illustrate that Summer wants to initiate to share about something, in this case, her feeling about August. The word 'like' in the previous may depict that Summer enjoys being friend with August.

In Summer's statement 'I feel like I can tell you anything' (line 2) may indicate that she thinks August is a trustworthy person. It can be showed by the phrase 'tell you anything' which may mean that she can share everything to him. As his response of Summer's opinion, August said 'cool beans' which this slang term describes something is excellent or wonderful (Kipfer and Chapman, 2007) may also define that he likes and feels delightful to be trusted whereas not everyone can keep a secret.

Based on the analysis above, it can be inferred that the addressing term of nickname in this data shows especially trustworthiness in solidarity behaviour (Lindenberg et al, 2006:21). It is seen from Summer's opinion about August and being friend with him.
Data 4
(1) "Is that a pumpkin?" I said, pointing to a framed painting behind Mr.
(2) Tushman's desk.
(3) "Auggie, sweetie, don't interrupt," said Mom.
(4) "You like it?" said Mr. Tushman, turning around and looking at the
(5) painting. "I do, too. And I thought it was a pumpkin, too, until the
(6) student who gave it to me explained that it is actually not a pumpkin. It
(7) is . . are you ready for this . . a portrait of me! Now, August, I ask
(8) you: do I really look that much like a pumpkin?"

The narrator in this data was August. The conversation placed in the Mr. Tushman's office, the headmaster of Breecher Prep School where August would enter. August and his mother came to the school to meet the headmaster and to talk about what August would need and do there. In the friendly situation, August's mother stated 'Auggie, sweetie, don't interrupt' (line 1) consists of addressing terms 'Auggie','sweetie', and 'August' which all of them refers to August. Both 'Auggie' or 'sweetie' are often used between people who know each other well (Holmes, 2013:13) and show an even greater intimacy (Wardhaugh, 2006:268). In line 3, August's mom uses both nickname and endearment to his son may signal a rebuke which can be seen by the following utterance 'don't interrupt'. The using of addressing terms by August's mother may emphasize that she warns August to respect his headmaster and also to avoid an offense. It is different with the addressing term 'August' that Mr. Tushman used in line 7 which shows a desire for such intimacy (Ibid, 2006:268). It can be showed by his utterance 'I ask you: do I really look that much like a pumpkin?' which may depict that he tries to be close by receiving his question. The using of addressing terms by the mother and Mr. Tushman may illustrate that they try to amend the mishap situation. August's mother called his son's nickname and added the endearment name may depict she mitigates August's offensiveness. On the other hand, Mr. Tushman used the addressing term of first name "August" is may indicate that he 
wants to attract August and also to attempt to be close by asking August's opinion and answering his question.

In conclusion, the addressing terms in this data which used by August's mother and his headmaster define a Lindenberg's idea about solidarity behaviour of considerateness (2006:21). The prohibition of mother and asking opinion from headmaster shows considerate from parents to their children.

\section{Endearment Name}

\section{Data 1}

(1) "My name is August," I said, and yeah, I kind of mumbled it.

(2) "What?" said someone.

(3) "Can you speak up, honey?" said Ms. Petosa.

(4) "My name is August," I said louder, forcing myself to look up.

(5) "I, um ... have a sister named Via and a dog named Daisy. And, um ...

(6) that's it."

(7) "Wonderful," said Ms. Petosa. "Anyone have questions for August?"

In the data above, the dialogue was in the classroom in the first day of school and his teacher, Ms. Petosa, in friendly situation asked her students to introduce themselves in front of class. In line 3, Ms. Petosa used an addressing terms of 'honey' which refers to August appropriately used downwards in status (Holmes, 2013:15), in this case between teacher and student that may indicate her affection. Her utterance 'Can you speak up, honey?' may illustrate her effort to help August, who is a new student that came to regular school for the first time, to speak louder. It can be seen from the way August introduce himself in line 1 may illustrate that he feels uneasy to speak in front of class. The teacher's utterance here may depict that she attempts to make a common good situation which could make August speak louder. It can be proven by August's response by speaking louder and continuing his introduction (line 5).

The addressing terms of endearment name 'honey' in the data above indicates that she shows her solidarity behaviour of cooperation (Lindenberg et al, 2006:21) to her students to make them feel comfort and confident in the class.

\section{Data 2}

(1) "How does it sound, Auggie?" said the ear doctor. "Can you hear me

(2) okay, buddy?"

(3) I looked at him and smiled but I didn't answer.

(4) "Sweetie, do you hear anything different?" said Mom.

(5) "You don't have to shout, Mom." I nodded happily.

(6) "Are you hearing better?" asked the ear doctor. "I don't hear that noise

(7) anymore," I answered. "It's so quiet in my ears."

This dialogue above took place in the hospital where August consulted his ears trouble. In this friendly situation, the doctor used August's nickname, which is usually used to address friends or acquaintances directly (Mashiri, 1999:98), which may illustrate that he treats him as an intimate. In line 2, the term 'buddy' means a friend which usually used for a man or boy (thefreedictionary) defining that the doctor treats August as a friend. August's mother uses 'Sweetie' to August which is usually mentioned by parents to address their children to imply 
intimacy (Ibid, 1999:102). It may also illustrate that she is anxiety about August's hearing which can be enriched by the following utterance 'do you hear anything different?' (line 1). It may indicate that she convinces to August that he does not get a difficulty in hearing. August's response by saying 'You don't have to shout, Mom' may depict he is really well. This endearment name 'sweetie' which used by August's mother conveys her care about his hearing condition. It is in same line with Lindenberg's explanation about Altruism of solidarity (2006:21)

Thus, based on the analysis above 'sweetie' which includes of endearment name in addressing term depict a solidarity and intimacy between mother and child.

\section{Data 3cetak miring}

(1) "Everyone will stare at me at school," I said, suddenly crying.

(2) "Honey," Mom said. She turned around in the front seat and put her

(3) hand on my hand. "You know if you don't want to do this, you don't

(4) have to. But we spoke to the principal there and told him about you

(5) and he really wants to meet you."

(6) "What did you tell him about me?"

(7) "How funny you are, and how kind and smart. When I told him you

(8) read Dragon Rider when you were six, he was like, 'Wow, I have to

(9) meet this kid.' "

The conversation happened in the car where August' parents discussed about their plan to enroll him in the Breecher Prep School. August's mother used 'Honey' in line 2 as a form of an effort to calm him down in such worried feeling in his first day school. This term also shows a special name that was given by parents to their children (Landau, 2016) which expresses her affection. It can be reinforced by the following utterance in line 3 that states 'You know if you don't want to do this, you don't have to' which may indicate that she attempts to lighten August's anxiety. In line 4, she adds 'But we spoke to the principal there and told him about you and he really wants to meet you' that may illustrate that she tries to persuade her son to go to school. It can be seen by August's response 'What did you tell him about me?' which may depict his anxiety and worry about the possible effect the principle may have concerning his face defect. The phrase 'really wants to meet' here may mean she emphasizes August that the headmaster like him which can be enriched by some utterances in line $7-9$. Those utterances also may define that she tries to convince her son that he has some good thing about him and it depicts a mother's considerateness (Lindenberg et al, 2006:22) to her child when he felt scared and worry. Based on the analysis above, it can be concluded that the addressing term of endearment name 'Honey' which stated by August's mother conveys her care and to show her solidarity when his son felt afraid to meet people.

The use of addressing terms which is addressed to the same person can be having different meaning. It is based on the situation where the speaker addresses the hearer and also the purpose of the speaker. For instance, in the same situation and the addressing term of first name which is used to the same person can have different aims such as, a student addresses his/her classmates by their first names in school to show their relationship or to indicate a solidarity between them. By mentioning first name in other situation, like parents call their children when they are arguing may signal their status in family or to show their considerateness. The other kinds of addressing terms is kinship term, which is usually used among the family member, in different situation children addressing their parents by using 
kinship term to convey a divergent aim. For example, based on the data above, August calls her mother 'mom' to convey his protest, while his sister calls 'mom' to convince her mother. On the other way, the addressing terms of endearment name often used by parents to call their children it usually has the same meaning as a sign of affection in the same situation, like August's mother, Summer's mother, even Jack's mother call them with endearment names to express their love. Sometimes people also addressing each other by nicknames, a person can have more than one nicknames. Like August, he has been called 'Auggie', 'Major Tom', 'dude', and 'buddy' by his friends. These various names refers to the same person which in the same situation can be the same meaning as solidarity behaviours of considerateness. Based on the novel, the most frequently addressing terms that is used among the characters are first name and nickname. Those addressing terms indicate considerable intimacy. In the other side, the endearment name is the lowest term that is used by the characters which depicts an affection.

\section{CONCLUSION}

Based on the findings and analysis above, there are 4 kinds of addressing terms that are used by the characters in the novel entitles "Wonder" by R.J. Palacio, such as mentioning first name, using kinship term, calling nickname, and endearment name. Those kinds of addressing terms are used in different ways by the characters to show their solidarities. The addressing terms of first name, which according to the data analysis, are used by August to Jack is a way to show his willingness to cooperate. It is not similar with how Jack calls August by first name to reveal his care to him. Using kinship term which is usually used among family members more often to show their considerateness in any situation and it is same as in using endearment name which reveals more even greater intimacy. Calling someone by a nickname shows the closeness relationship between them. Based on Fasold's opinion that states nickname is also used to symbolize a friendship (1990:10) which is depicted in the data, for instance Jack calls August 'dude' and an ear doctor calls him 'buddy' which have same meaning to help August in any situation. People have different addressing terms that are used to addressing the same person based in the situation where they are talking. They also choose which kind of addressing terms used to somebody to convey their purposes. For examples, in trying to be close, sometimes people use first name or nickname. Children use the kinship term to their parents to respect them, in contrary, parents call their children by using endearment names to define their affection. The different person in different situations influences people to choose the addressing term that will be used. For instance, when people get in serious or quarreling situation, they use endearment names or nicknames to amend the situation and also to avoid offending the other. Meanwhile, in friendly situation, people addressing another by using first name or nickname to make them be closer such as Jack called August Pullman by his first name.

\section{REFERENCES}

Azin, N and Akbar Afghari. (2015). The Study of Persian Address Terms in Young Adult Novels According to the Politeness Theory. Mediterranean Journal of Social Sciences. Vol 6 No 5 S1, September 2015

Berg, Bruce L. (2007). Qualitative Research Methods for the Social Sciences. 6th Edition. San Francisco: Pearson Education, Inc

Elliott, R. (1999). Editor's introduction to special issue on qualitative psychotherapy research : Definitions, themes and discoveries. Psychotherapy Research. 
Vol.9 : 251-257.

Fasold, R. (1990). Sociolinguistics of Language. Oxford: Blackwell.

Holmes, Janet. (2013). An Introduction to Sociolinguistics. London: Routledge.

Kiesling, Scott F. (2004). Dude. American Speech. Vol. 79:281-305

Kipfer, Barbara Ann and Robert L. Chapman. (2007). The Dictionary of American Slang,

Fourth Edition. HarperCollins Publishers.

Lindenberg, Siegwart, et al (Eds.). (2006). Solidarity and Prosocial Behaviour. New York: Springer.

Mashiri, Pedzisai.(1999). Terms of Addressing in Shona: A Sociolinguistic Approach. Zambezia. Vol. XXVI: 93-110

Palacio, Raquel J. (2012). Wonder. New York: Alfred A.Knopf

Paltridge, B. (2006). Discourse Analysis. An Introduction. London : Continuum

Pongweni, A. J. C. (1982). What's in a Name?. Gweru: Mambo Press.

Wardhaugh, Ronald. (2006). An Introduction to Sociolinguistics (5th Ed). Victoria: Blackwell Publishing.

Yule, George. (2010). The Study of Language (4th Ed). New York: Cambridge University Press. 